\title{
VALUATION OF FINANCIAL PERFORMANCE AND STOCK PERFORMANCE

\author{
(Case Study PT Holcim Indonesia Tbk)
}

\author{
Yuniza Nurunniza \\ Management Department, Sekolah Tinggi Ilmu Ekonomi Kesatuan, Bogor, \\ Indonesia, 16123 \\ Yoyon Supriadi \\ Management Department, Sekolah Tinggi Ilmu Ekonomi Kesatuan, Bogor, \\ Indonesia, 16123
}

\begin{abstract}
The main purpose of a company is to prosper the shareholders. The shareholders will get profit from the company they own after one year of operation by selling their products or services. Therefore, company's manager has responsibility to regulate the company to be profitable and needs to know and analyze how was the company has performed for period of time so the manager could correct mistakes in the decision making and maintain the company's strengths.

Besides the company's manager, the shareholders also need to know about how the company's performance to monitor whether investments they have is need to defend or could be abandoned. Succeed or not the management of a company written in annual report contained financial report or financial statement. Company and the shareholders need to understand the valuation of financial performance from the financial statement which are financing, asset management and profitability, also stock performance which consider the share market price in the stock exchange.

This financial and share performance research is studied to PT Holcim Indonesia Tbk in cement industry who has gotten loss for two years, then compare with companies in the same subsector in Indonesia Stock Exchange. The used research data is financial report for year 2012 until 2016 which are secondary data obtained from Indonesia Stock Exchange.

The result of the research shows that compare to the companies in the same industry, PT Holcim Indonesia Tbk from 2012 until 2016 has decreased performance escpecially in profitability. It was caused of the sales were not optimal and cost inefficiency, that caused stock price is declining. During those five years, PT Holcim Indonesia Tbk expanded it's company which is financed by debt, so PT Holcim Indonesia being a company that the operation dominant use of debt.
\end{abstract}

Keywords : Profitability, Asset Management, Financing, Stock 


\section{PENDAHULUAN}

Indonesia masuk sebagai peringkat ke-tiga negara dengan produksi semen tertinggi di Asia-Pasifik, total kapasitas produksi yang pada tahun 2010 sebesar 37,8 juta ton menjadi mencapai 100 juta ton pada tahun 2017, sementara penjualan domestik juga melonjak dari 40 juta ton menjadi sekitar 65 juta ton pada periode yang sama.

Konsumsi semen di sebuah negara menggambarkan bagaimana pembangunan infrastruktur negara tersebut karena semen merupakan komponen utama dalam pembangunan infrastruktur seperti jalan tol, jembatan, pelabuhan, dan lain-lain. Indonesia merupakan salah satu negara dengan pembangunan infrastruktur yang sedang berkembang, sehingga permintaan terhadap semen juga bertambah dan banyak perusahaan semen baru baik dari dalam negeri maupun luar negeri yang terus bermunculan untuk memanfaatkan peluang yang ada. Hal tersebut juga yang menyebabkan bertambahnya kapasitas produksi semen Indonesia.

\section{Identifikasi Masalah}

1. Bagaimana struktur pendanaan pada PT Holcim Indonesia Tbk

2. Bagaimana manajemen aset pada PT Holcim Indonesia Tbk

3. Bagaimana kemampulabaan pada PT Holcim Indonesia Tbk

4. Bagaimana Kinerja saham PT Holcim Indonesia Tbk.

\section{METODOLOGI PENELITIAN}

\section{Deskriptif}

Penelitian deskriptif (descriptive research) adalah suatu metode penelitian yang bertujuan untuk memberikan gambaran yang lebih terinci mengenai suatu gejala atau fenomena, dalam proposal skripsi ini berkaitan dengan kinerja keuangan dan saham perusahaan. Fenomena yang diteliti merupakan kejadian yang sedang berlangsung pada saat ini maupun saat yang lampau. Penelitian desktriptif ini menjelaskan aspek-aspek yang relevan dengan fenomena yang di amati.

Metode deskriptif juga didefinisikan sebagai proses pemecahan masalah yang diselidiki, dengan menggambarkan atau melukiskan keadaan objek 
penelitian pada saat sekarang, berdasarkan fakta-fakta yang tampak atau sebagaimana adanya.

\section{Kuantitatif}

Kuantitatif adalah suatu proses menemukan pengetahuan yang menggunakan data berupa angka sebagai alat menganalis keterangan mengenai apa yang ingin diketahui. Metode kuantitatif juga merupakan metode yang dapat menguji teori tertentu yang sudah dengan cara meneliti hubungan antar variabel.

Untuk dapat melakukan pengukuran menggunakan metode kuantitatif, setiap fenomena di jabarkan kedalam beberapa komponen masalah. Teknik perhitungan secara kuantitatif dapat dilakukan sehingga dapat menghasilkan suatu simpulan. Tujuan utama dari metodologi ini adalah menjelaskan suatu masalah tetapi menghasilkan generalisasi. Generalisasi ialah suatu kenyataan kebenaran yang terjadi didalam suatu realitas tentang suatu masalah yang diperkirakan.

\section{Rasio utang (Debt Ratios)}

a. Debt Ratio

Rasio ini digunakan untuk mengetahui bagaimana perusahaan mendanai baik untuk aktiva lancar maupun aktiva tetap dalam menunjang kegiatan usahanya. Apakah perusahaan lebih banyak menggunakan dana dari pemilik (saham/ekuitas) atau dari sumber hutang. Dengan demikian rasio ini memberikan indikator tentang besarnya utang yang digunakan perusahaan untuk mendanai seluruh aktiva yang dimiliki.

$$
\text { Debt Ratio }=\frac{\text { Total Debt }}{\text { Total Assets }}
$$

Rasio ini juga dapat digunakan untuk mengukur solvabilitas perusahaan. semakin kecil angka rasio ini berarti perusahaan semakin kecil memanfaatkan dana-dana dari sumber hutang, dan berarti pula kondisi perusahaan semakin solvabel.

b. Debt to Equity Ratio

Rasio ini menggambarkan struktur modal perusahaan. Karena berkaitan dengan permodalan perusahaan yang berarti menyangkut 
dana-dana yang diperoleh perusahaan melalui hutang, maka angka total utang yang akan digunakan. Total utang tersebut dibandingkan dengan total ekuitas atau modal pemilik perusahaan. Dengan kata lain rasio ini merupakan perbandingan antara utang yang dimiliki perusahaan dengan modal yang dimiliki perusahaan. Rasio ini menunjukkan kemampuan modal yang dimiliki oleh perusahaan dalam memenuhi seluruh kewajiban.

$$
\text { Debt to Equity Ratio }=\frac{\text { Total Debt }}{\text { Equity }}
$$

c. Rasio Pencakupan (Coverage Ratio)

Coverage ratio adalah rasio yang mengukur tingkat keamanan suatu perusahaan dalam hal kemampuan membayar bunga pinjaman, atau menggambarkan kemampuan hasil operasional perusahaan untuk menutupi kewajiban bunga. Yaitu menggunakan rumus Times Interest Earned ratio.

$$
\mathrm{TIE}=\frac{\text { Earning Before Interest and Tax }}{\text { Interest Expense }}
$$

Menilai efektivitas manajemen aset dalam suatu perusahaan dapat dengan melakukan analisis rasio yaitu rasio aktivitas dan likuiditas.

\section{Rasio Aktivitas (Activity Ratios)}

a. Total Assets Turnover (TATO)

$$
\text { TATO }=\frac{\text { Revenue }(\text { sales })}{\text { Total Assets }}
$$

b. Current Asset Turnover (CATO)

$$
\text { CATO }=\frac{\text { Revenue }(\text { Sales) }}{\text { Current Assets }}
$$


c. Fixed Assets Turnover (FATO)

$$
\text { FATO }=\frac{\text { Revenue (Sales) }}{\text { Fixed Assets }}
$$

d. Inventory Turnover (InTO)

$$
\operatorname{InTO}=\frac{\text { Cost of Good Sold }}{\text { Inventory }}
$$

e. Accounts Receivable Turnover (ARTO)

$$
\text { ARTO }=\frac{\text { Revenue }(\text { Sales })}{\text { Account Receivable }}
$$

f. Working Capital Turnover (WCTO)

$$
\text { WCT0 }=\frac{\text { Revenue (Sales) }}{\text { Working Capital }}
$$

g. Account Payable Turnover (APTO)

$$
\text { APTO }=\frac{\text { Cost of Good Sold }}{\text { Accounts Payable }}
$$

\section{Rasio Likuiditas (Liquidity Ratios)}

a. Rasio Lancar (Current Ratio)

$$
\text { Current Ratio }=\frac{\text { Current Assets }}{\text { Current Liabilities }}
$$

b. Rasio Cepat (Quick Ratio)

$$
\text { Quick Ratio }=\frac{\text { Current Assets }- \text { Inventories }}{\text { Current Liabilities }}
$$


c. Rasio Kas (Cash Ratio)

$$
\text { Cash Ratio }=\frac{\text { Cash or Cash Equivalent }}{\text { Current Liabilities }}
$$

4. Kemampulabaan (Profitability Ratios)

a. Gross Profit Margin (GPM)

$$
\mathrm{GPM}=\frac{\text { Gross Profit }}{\text { Sales }}
$$

b. Operating Profit Margin (OPM)

$$
\mathrm{OPM}=\frac{\text { Operating Profit Margin }(E B I T)}{\text { Sales }}
$$

c. Net Profit Margin (NPM)

$$
\mathrm{NPM}=\frac{\text { Earning After Tax }(\text { EAT })}{\text { Sales }}
$$

d. Return on Assets (ROA)

$$
\mathrm{ROA}=\frac{\text { Earning After Tax (EAT) }}{\text { Total Assets }}
$$

e. Return on Capital Employed (ROCE)

$$
\text { ROCE }=\frac{\text { EBIT }}{\text { Long term debt }+ \text { Equity }}
$$

f. Return on Equity (ROE)

$$
\mathrm{ROE}=\frac{\text { Earning After Tax (EAT) }}{\text { Equity }}
$$




\section{Kinerja Saham (Stock Performance)}

1. a. Earning per Share (EPS)

$$
E P S=\frac{E A T}{J_{s b}}
$$

Dimana :

EAT $=$ Earning After Tax atau pendapatan setelah pajak

$\mathrm{Jsb}=$ Jumlah saham yang beredar

b. Price Earning Ratio (PER)

$$
\text { PER }=\frac{\text { MPS }}{\text { EPS }}
$$

Dimana:

MPS = Market Price per Share (harga pasar per lembar saham)

EPS = Earning per Share (laba per lembar saham)

c. Book Value per Share (BVS)

$$
\text { BVS }=\frac{\text { Total modal sendiri }- \text { saham preferen }}{\text { saham biasa yang beredar }}
$$

d. Price to Book Value (PBV)

$$
B V=\frac{\text { Harga per lembar saham }}{\text { Nilai buku ekuitas per lembar saham }}
$$


ANALYSIS

Analisis Rasio atas Pendanaan PT Holcim Indonesia Tbk

Berikut ini adalah analisis rasio atas pendanaan PT Holcim Indonesia Tbk.

\section{Solvabilitas}

Perhitungan pada rasio ini akan menunjukkan porsi utang terhadap aset dan terhadap ekuitas yang dimiliki oleh PT Holcim Indonesia Tbk.

\section{Debt to Asset Ratio}

Berikut ini adalah grafik perbandingan Debt to Asset Ratio SMCB dan Rata-Rata Industri.

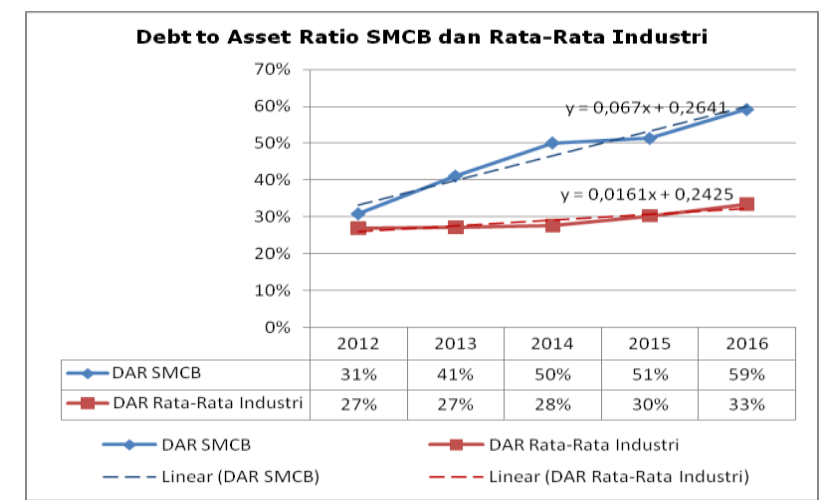

Grafik Perbandingan Rasio DAR PT Holcim Indonesia Tbk dan Rata-Rata Industri tahun 2012-2016

Grafik menunjukkan bahwa perbandingan utang terhadap aset yang dimiliki oleh SMCB dan rata-rata industri sama-sama memiliki tren yang meningkat. Tetapi dari kedua garis pada grafik tersebut terlihat bahwa SMCB memiliki peningkatan rasio DAR yang lebih besar daripada rata-rata industri yang memberikan arti bahwa peningkatan utang SMCB lebih tinggi daripada peningkatan total aset yang dimilikinya.

Kemudian berdasarkan bobot utang terhadap aset, rata-rata perusahaan di sektor semen memiliki rasio DAR yang masih dibawah $40 \%$ yaitu jika dibandingkan dengan aset, penggunaan utang tidak dominan. Lain dengan SMCB yang memiliki rasio DAR yang telah berada diatas $50 \%$. 


\section{Debt to Equity Ratio}

Berikut ini adalah grafik perbandingan Debt to Asset Ratio SMCB dan Rata-Rata Industri.

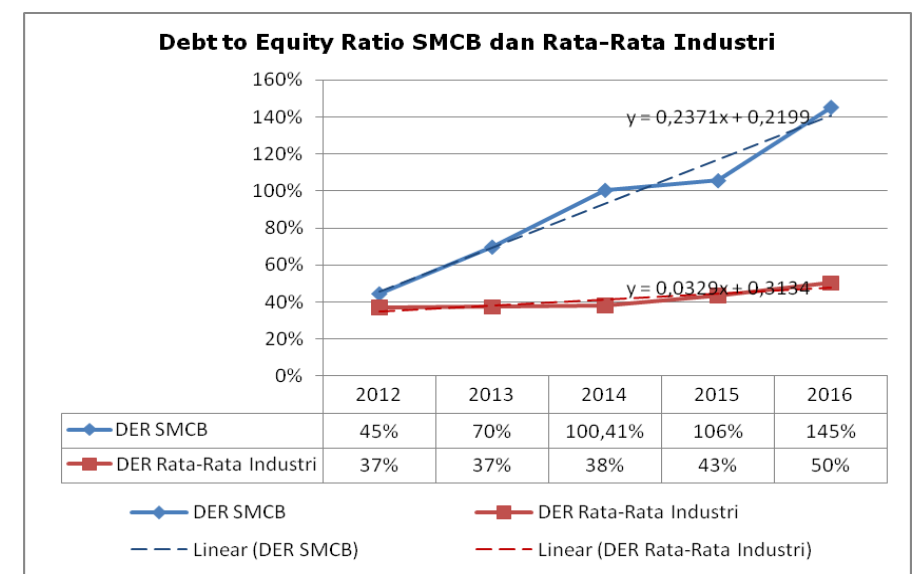

Grafik Perbandingan Rasio DER PT Holcim Indonesia Tbk dan Rata-Rata Industri tahun 2012-2016

Grafik menunjukkan bahwa perbandingan utang dan ekuitas pada ratarata industri lebih memiliki kecenderungan yang mendatar walaupun terdapat peningkatan sedikit, berbeda dengan SMCB yang meningkat secara signifikan. Kemudian dilihat dari angka perbandingan antara utang dan ekuitas, SMCB memiliki utang yang pada tahun 2014 sama jumlahnya dengan ekuitas pada tahun tersebut, kemudian tahun 2015 dan 2016 jumlah utang SMCB telah melebihi jumlah ekuitas yang dimilikinya. Hal ini lebih menunjukkan kembali bahwa SMCB beroperasi dominan menggunakan utang selama tahun 2014-2016 dimana peningkatan utang setiap tahunnya lebih besar daripada peningkatan ekuitas yang dimiliki SMCB.

\section{Coverage (Times Interest Earned)}

Perhitungan pada rasio ini akan menunjukkan kemampuan SMCB dalam membayar bunga yang muncul akibat utang. Berikut ini adalah grafik perbandingan Times Interest Earned SMCB dan Rata-Rata Industri. 


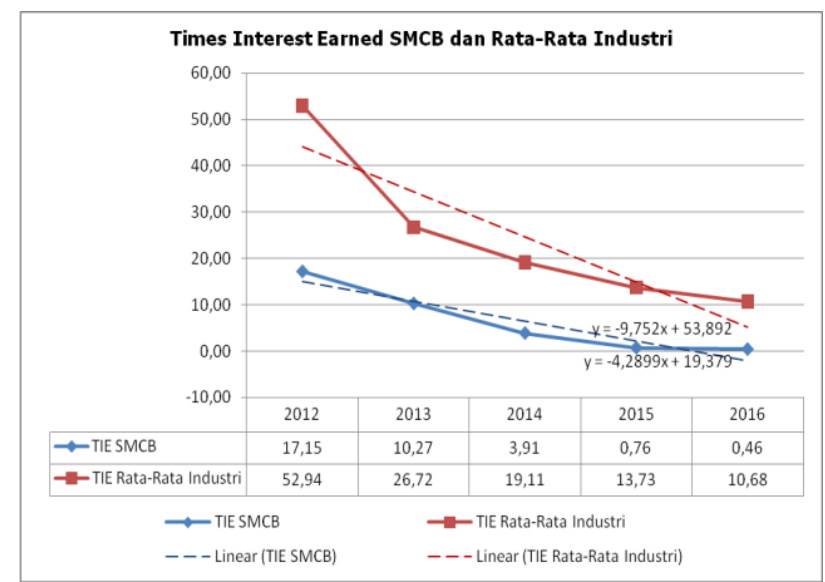

Grafik Perbandingan Rasio TIE PT Holcim Indonesia Tbk dan Rata-Rata Industri tahun 2012-2016

Grafik menunjukkan rasio TIE SMCB dan rata-rata industri memiliki tren yang menurun yang memberikan arti bahwa menurun pula kemampuan seluruh perusahaan di industri atau subsektor semen dalam membayar bunga. Pada grafik tersebut juga diperlihatkan bahwa penurunan rasio TIE rata-rata industri lebih signifikan daripada rasio TIE SMCB dan penurunan rasio TIE terbesar ada pada tahun 2013 yang disebabkan peningkatan yang signifikan pada beban bunga ratarata industri.

Kemudian garis rasio TIE SMCB berada dibawah garis rasio TIE rata-rata industri yang berarti dalam hal coverage atau menutupi beban bunga oleh EBIT, SMCB memiliki kemampuan yang lebih rendah dibandingkan dengan rata-rata industri.

\section{Aktivitas dan Profitabilitas}

Perhitungan pada rasio ini akan menunjukkan efektivitas pendanaan SMCB dalam menghasilkan penjualan dan laba yaitu EBIT, kemudian dibandingkan dengan rasio yang dihasilkan oleh rata-rata Industri.

\section{Account Payable Turn Over}

Berikut ini adalah grafik perbandingan Rasio Account Payable Turn Over SMCB dan Rata-Rata Industri 2012-2016. 


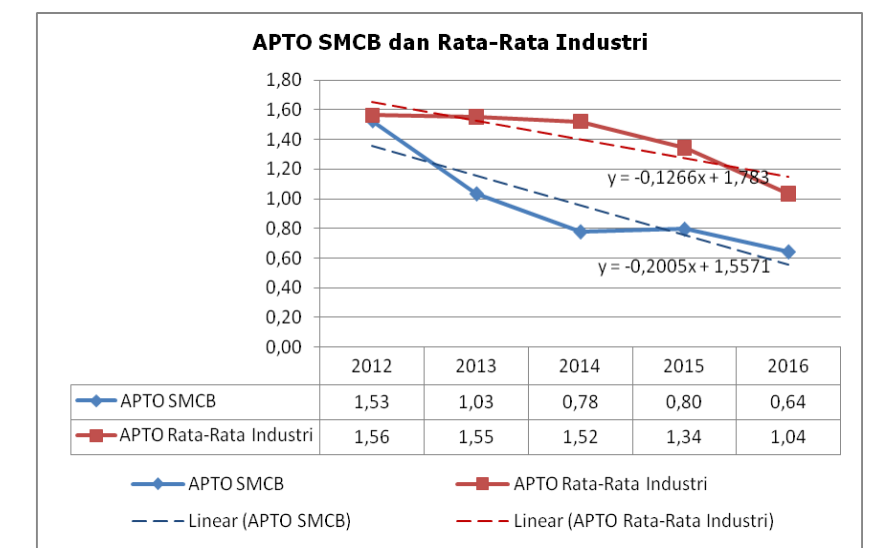

Grafik Perbandingan Rasio APTO PT Holcim Indonesia Tbk dan Rata-Rata Industri tahun 2012-2016

Grafik menunjukkan bahwa baik SMCB maupun rata-rata industri, memiliki rasio APTO yang memiliki kecenderungan yang menurun. Namun berdasarkan grafik tersebut, perputaran utang yang dimiliki oleh SMCB memiliki tren yang lebih menurun dan lebih kecil daripada rata-rata industri, yang berarti selama lima tahun tersebut SMCB membayar utang lebih lambat daripada rata-rata industri. Seperti yang telah dijelaskan dalam teori bahwa perputaran utang sebaiknya tidak lebih cepat daripada perputaran piutang, maka berikut ini adalah tabel rata-rata umur utang dan piutang yang dimiliki oleh SMCB.

Rata-Rata Umur Utang dan Piutang PT Holcim Indonesia Tbk tahun 2012-2016

\begin{tabular}{lrrrrrr}
\hline \multirow{1}{*}{ Keterangan } & \multicolumn{5}{c}{ Tahun } & $\begin{array}{c}\text { Rata- } \\
\text { Rata }\end{array}$ \\
\cline { 2 - 5 } & 2012 & 2013 & 2014 & 2015 & 2016 & \\
\hline Umur Utang & 239 hari & 353 hari & 469 hari & 459 hari & 567 hari & 417 hari \\
$\begin{array}{l}\text { SMCB } \\
\text { Umur Piutang }\end{array}$ & 33 hari & 36 hari & 40 hari & 44 hari & 40 hari & 39 hari \\
Rata-Rata Industri
\end{tabular}

Tabel menunjukkan bahwa rata-rata umur utang SMCB jika dibandingkan dengan rata-rata umur piutangnya, lebih lama rata-rata umur piutang. Hal ini berarti pada saat utang yang dimiliki oleh SMCB jatuh tempo, SMCB telah memiliki dana untuk membayar utang tersebut.

\section{Fixed Asset Turn Over}

Berikut ini adalah grafik perbandingan Fixed Asset Turn Over Ratio SMCB dan Rata-Rata Industri. 


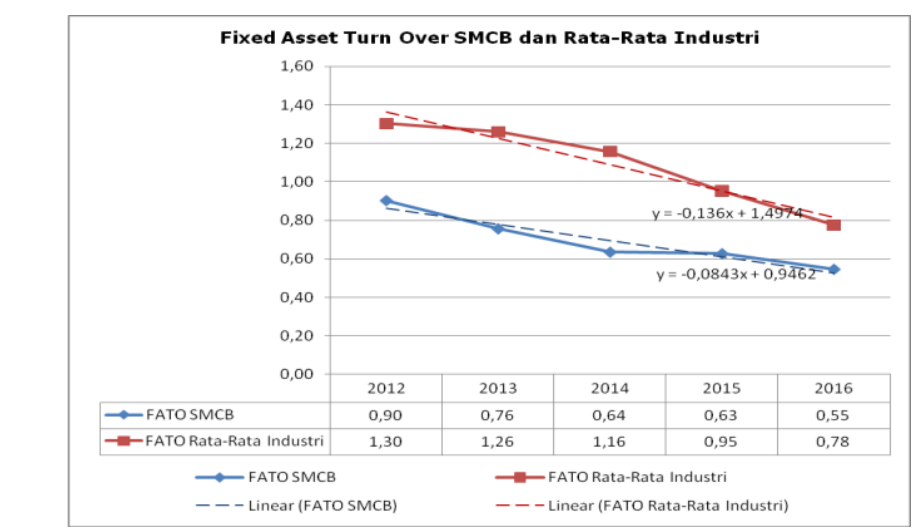

Grafik Perbandingan Rasio FATO PT Holcim Indonesia Tbk dan Rata-Rata Industri tahun 2012-2016

Grafik menunjukkan bahwa efektivitas pengelolaan aset tidak lancar untuk menghasilkan penjualan baik milik SMCB maupun rata-rata industri menurun. Hal ini menunjukkan bahwa terdapat hal eksternal perusahaan yang mempengaruhi perusahaan-perusahaan yang berada di sektor semen sehingga efektivitas pengelolaan aset tetapnya menurun dimana perusahaan-perusahaan di sektor semen sangat bergantung pada aset tetap dalam pembuatan produksinya.

Kemudian garis grafik rasio FATO SMCB yang berada dibawah rata-rata industri menunjukkan bahwa efektivitas pengelolaan aset tidak lancar jika dibandingkan dengan rata-rata industri masih sangat kecil.

Pada tahun 2014-2015 garis rasio FATO SMCB landai, dibandingkan dengan rata-rata industri yang menurun. Hal ini disebabkan oleh penjualan SMCB yang pada tahun tersebut menurun sedikit namun terjadi penurunan penjualan yang cukup besar di rata-rata industri dimana pada tahun 2015 WSBP tergabung dalam kelompok industri namun penjualannya tidak memberikan pengaruh yang tinggi sehingga ketika dirata-ratakan, hasil dari penjualan rata-rata industri menurun pada tahun tersebut.

\section{Current Asset Turn Over}

Berikut ini adalah grafik perbandingan Current Asset Turn Over Ratio SMCB dan Rata-Rata Industri. 


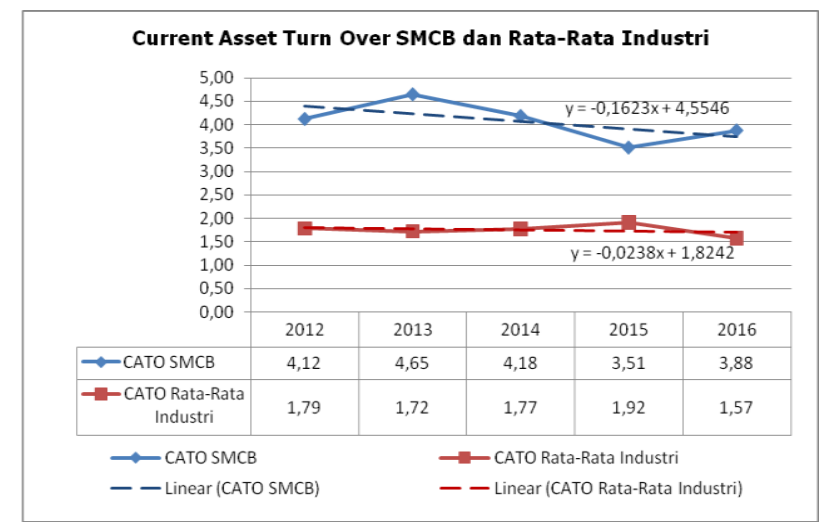

Grafik Perbandingan Rasio CATO PT Holcim Indonesia Tbk dan Rata-Rata Industri tahun 2012-2016

Gambar menunjukkan bahwa efektivitas pengelolaan aset lancar SMCB dalam menghasilkan penjualan memiliki tren yang menurun dan jika dibandingkan dengan efektivitas pengelolaan aset lancar rata-rata industri, maka rasio CATO rata-rata industri memiliki tren atau kecenderungan yang stabil. Namun dari kedua garis dalam grafik tersebut, angka rasio CATO yang dihasilkan oleh SMCB lebih tinggi daripada rata-rata industri. Hal ini disebabkan oleh jumlah kas SMCB yang cenderung rendah. Namun angkanya memang fluktuatif. Sebagai contoh, pada tahun 2012 jumlah aset lancar yang dimiliki SMCB adalah sebesar Rp556 miliar sedangkan aset lancar dari yang dimiliki oleh perusahaanperusahaan yang berada pada industri atau sektor yang sama dengan SMCB berada pada angka Rp3 triliun. Sehingga walaupun penjualan yang dihasilkan SMCB berada dibawah rata-rata industri, rasio CATO SMCB dapat menghasilkan angka yang lebih besar karena aset lancarnya juga lebih kecil.

\section{Total Asset Turn Over}

Berikut ini adalah grafik perbandingan Total Asset Turn Over Ratio SMCB dan Rata-Rata Industri.

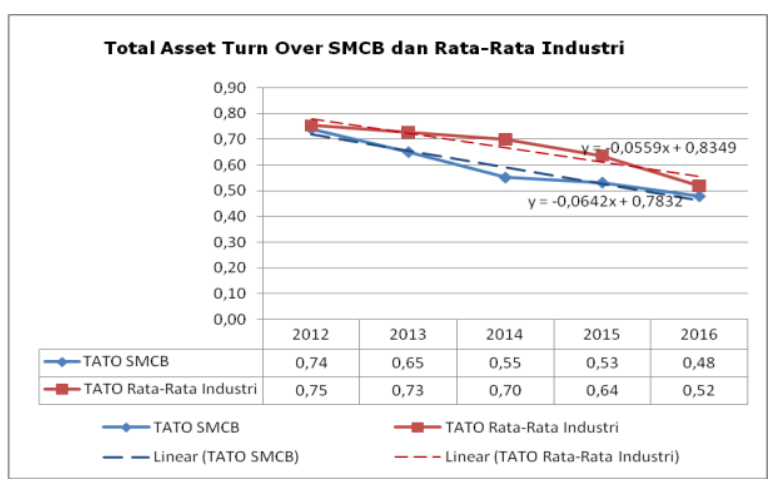

Grafik Perbandingan Rasio TATO PT Holcim Indonesia Tbk 
Berdasarkan grafik rasio TATO SMCB maupun rata-rata dalam industri memiliki kecenderungan yang menurun yang memiliki arti bahwa efektivitas pengelolaan total aset dari seluruh perusahaan yang berada di industri atau sektor semen mengalami penurunan. Namun berdasarkan angka hasil rasio tersebut, rasio TATO SMCB berada dibawah rata-rata industri. Pada tahun 2012 rasio TATO SMCB hampir berada pada titik yang sama dengan rata-rata industri yang memberikan gambaran bahwa pengelolaan total aset SMCB pada tahun tersebut hampir setara dengan efektifitas pengelolaan aset yang dimiliki perusahaanperusahaan didalam industri atau sektor semen.

\section{Inventory Turn Over}

Berikut ini adalah grafik perbandingan Inventory Turn Over Ratio SMCB dan Rata-Rata Industri.

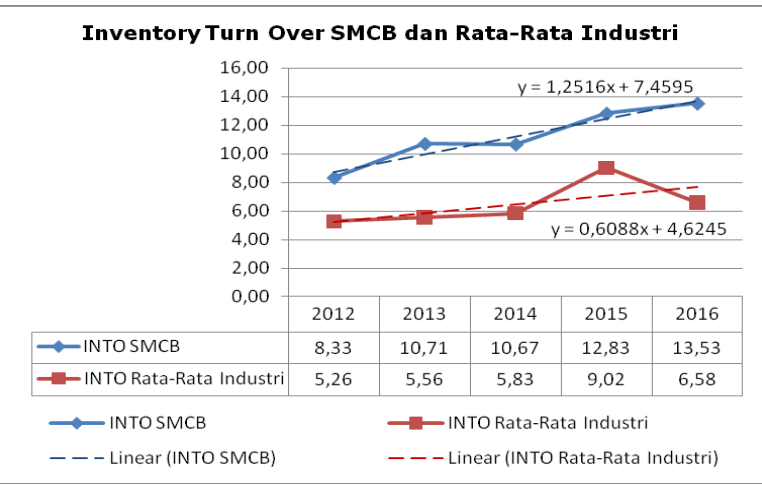

Grafik Perbandingan Rasio INTO PT Holcim Indonesia Tbk dan Rata-Rata Industri tahun 2012-2016

Berdasarkan grafik pada gambar 4.23, INTO SMCB dan Rata-Rata Industri memiliki tren yang meningkat. Hal ini menunjukkan bahwa jumlah produk terjual jika dibandingkan dari persediaan baik milik SMCB maupun rata-rata di industri juga meningkat pertahunnya dimana penjualan dari seluruh perusahaan disektor semen meningkat jika dilihat dari perbandingan dengan persediaan. Namun berdasarkan angka dari hasil rasio INTO tersebut, SMCB memiliki hasil yang lebih besar dibandingkan dengan rata-rata industri, atau berada diatas rata-rata. Untuk mengetahui rata-rata umur persediaan SMCB dan Rata-Rata Industri berdasarkan lama hari, berikut ini tabel dari siklus tersebut.

Rata-Rata Umur Persediaan PT Holcim Indonesia Tbk tahun 2012-2016 


\begin{tabular}{lcccccc}
\hline \multirow{2}{*}{ Keterangan } & \multicolumn{5}{c}{ Tahun } & Rata- \\
\cline { 2 - 6 } & 2012 & 2013 & 2014 & 2015 & 2016 & Rata \\
\hline Umur Persediaan & 44 & 34 & 34 & 28 & 27 & 34 \\
SMCB & hari & hari & hari & hari & hari & hari \\
Umur Persediaan & 69 & 66 & 63 & 40 & 55 & 59 \\
Rata-Rata Industri & hari & hari & hari & hari & hari & hari
\end{tabular}

Tabel menunjukkan bahwa waktu dimana persediaan SMCB berada digudang rata-rata terjual dalam waktu 34 hari, lebih cepat daripada yang dimiliki oleh rata-rata industri dimana rata-rata persediaan terjual dalam waktu 59 hari. Hal ini menunjukkan bahwa SMCB memiliki perputaran persediaan yang lebih baik daripada perusahaan-perusahaan lain yang berada disektor yang sama dengan SMCB yaitu semen.

\section{Account Receivable Turn Over}

Berikut ini adalah grafik perbandingan Account Receivable Turn Over Ratio SMCB dan Rata-Rata Industri.

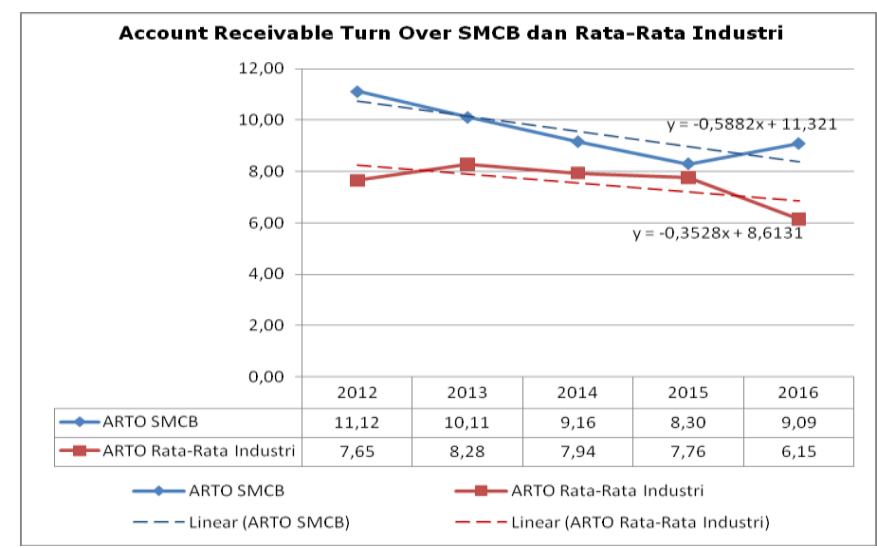

Gambar 4.24

Grafik Perbandingan Rasio ARTO PT Holcim Indonesia Tbk dan Rata-Rata Industri tahun 2012-2016

Berdasarkan grafik pada gambar 4.24, ARTO SMCB dan Rata-Rata Industri memiliki tren yang menurun. Hal ini menunjukkan bahwa jumlah kali pelunasan piutang baik milik SMCB maupun rata-rata di industri juga menurun pertahunnya. Namun berdasarkan angka dari hasil rasio INTO tersebut, SMCB memiliki hasil yang lebih besar dibandingkan dengan rata-rata industri, atau berada diatas rata-rata. Untuk mengetahui rata-rata umur piutang SMCB dan Rata-Rata Industri berdasarkan lama hari, berikut ini tabel dari siklus tersebut.

Rata-Rata Umur Piutang PT Holcim Indonesia Tbk tahun 2012-2016 


\begin{tabular}{lcccccc}
\hline \multirow{2}{*}{ Keterangan } & \multicolumn{5}{c}{ Tahun } & $\begin{array}{c}\text { Rata- } \\
\text { Rata }\end{array}$ \\
\cline { 2 - 6 } & 2012 & 2013 & 2014 & 2015 & 2016 & 39 \\
\hline Umur Piutang & 33 & 36 & 40 & 44 & 40 & 39 \\
SMCB & hari & hari & hari & hari & hari & hari \\
Umur Piutang & 48 & 44 & 46 & 47 & 59 & 49 \\
Rata-Rata & hari & hari & hari & hari & hari & hari \\
Industri & & & & & &
\end{tabular}

Tabel menunjukkan bahwa waktu dimana piutang SMCB dilunasi rata-rata terlunasi dalam waktu 34 hari, lebih cepat daripada yang dimiliki oleh rata-rata industri dimana rata-rata piutang dilunasi dalam waktu 59 hari. Hal ini menunjukkan bahwa SMCB memiliki perputaran piutang yang lebih baik daripada perusahaan-perusahaan lain yang berada disektor yang sama dengan SMCB yaitu semen.

\section{Rasio Likuiditas}

Perhitungan pada rasio ini akan menunjukkan likuditas atau kemampuan manajemen aset SMCB yaitu aset lancar dalam memenuhi kewajiban jangka pendeknya.

\section{Current Ratio}

Berikut ini adalah grafik perbandingan Current Ratio SMCB dan Rata-Rata Industri.

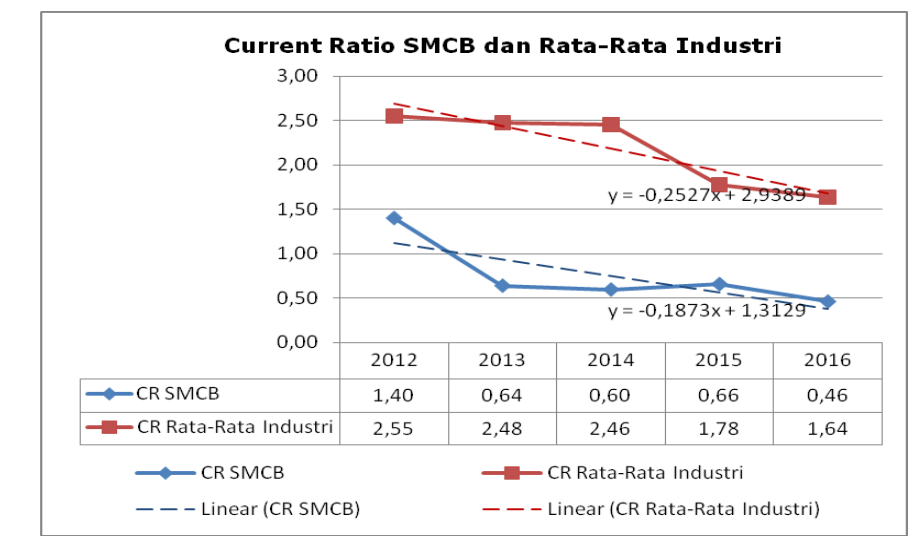

Grafik Perbandingan Current Ratio PT Holcim Indonesia Tbk dan Rata-Rata Industri tahun 2012-2016

Berdasarkan grafik Current Ratio SMCB dan rata-rata industri memiliki kecenderungan yang menurun dan garis dari tren keduanya hampir sejajar. Hal ini memberikan arti bahwa kemampuan memenuhi kewajiban atas utang lancar yang dimiliki perusahaan-perusahaan dalam sektor semen di Bursa Efek Indonesia juga 
menurun. Namun berdasarkan angka dari rasio tersebut, rasio CR SMCB berada dibawah rata-rata industri. Hasil rasio CR SMCB menunjukkan angka dibawah 1 yang berarti kemampuan menutupi utang lancar dari aset lancar SMCB tidak baik, yaitu lebih besar jumlah utang lancar daripada aset lancar yang dimiliki oleh SMCB.

Kemudian jika diteliti, rasio CR rata-rata industri pada tahun 2014-2015 menurun cukup signifikan. Hal ini disebabkan penurunan aset lancar pada perusahaan-perusahaan yang memiliki pangasa pasar yang tinggi yaitu INTP dan SMGR. Selain itu SMBR juga mengalami penurunan aset lancar pada tahun tersebut. Penurunan ini didominasi oleh penurunan kas dan setara kas perusahaanperusahaan tersebut.

\section{Quick Ratio}

Berikut ini adalah grafik perbandingan Quick Ratio SMCB dan Rata-Rata Industri.

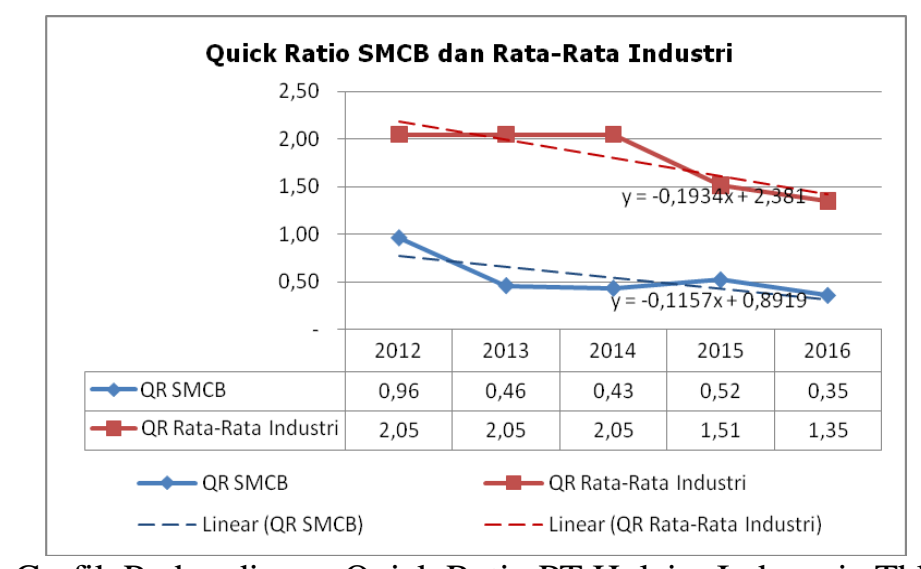

Grafik Perbandingan Quick Ratio PT Holcim Indonesia Tbk dan Rata-Rata Industri tahun 2012-2016

Grafik menunjukkan bahwa tren dari Quick Ratio yang dimiliki SMCB dan rata-rata industri menurun. Karena rasio $\mathrm{CR}$ yang dimiliki oleh SMCB berada dibawah rata-rata industri, maka rasio QR pun memiliki angka yang berada dibawah rata-rata industri. Dapat menjadi perhatian bahwa pada saat tahun 2012 sampai dengan tahun 2014 rasio QR rata-rata industri berada dalam angka yang stagnan atau stabil dikarenakan angka kas, persediaan dan utang lancar yang juga stabil, QR SMCB menurun akibat utang lancar yang meningkat signifikan yaitu sebesar 110\% dari jumlah Rp1,5 triliun menjadi Rp3,2 triliun. 


\section{Cash Ratio}

Berikut ini adalah grafik perbandingan Cash Ratio SMCB dan Rata-Rata Industri.

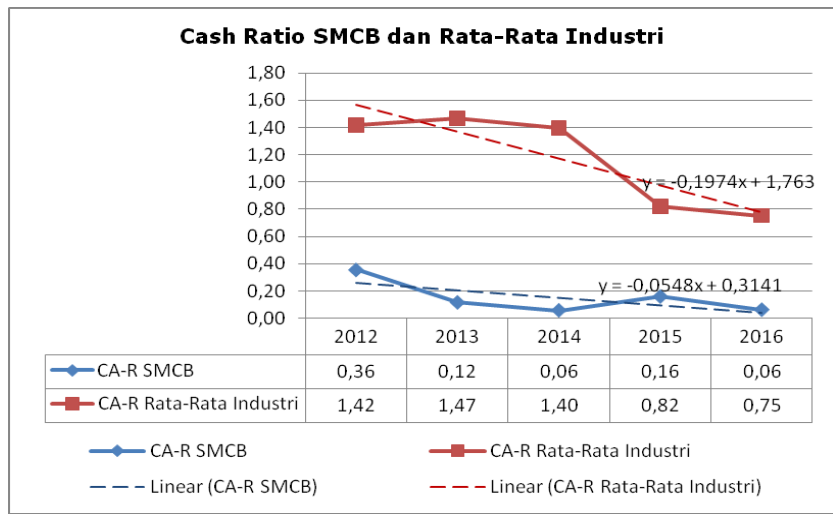

Grafik Perbandingan Cash Ratio PT Holcim Indonesia Tbk dan Rata-Rata Industri tahun 2012-2016

Berdasarkan grafik pada gambar 4.27, tren dari rasio Cash Ratio SMCB menurun tetapi tidak signifikan sehingga dapat dikatakan stabil walaupun fluktuatif. Kemudian kas dan setara kas SMCB ini memiliki porsi yang kecil dalam aset lancar karena penjualan SMCB dominan dengan piutang. Selanjutnya tren dari rasio CA-R rata-rata industri menurun yang disebabkan oleh penurunan yang signifikan pada tahun 2014 -2015. Hal ini memberikan bukti pada pernyataan bahwa terjadi penurunan kas dan setara kas yang signifikan pada tahun tersebut.

\section{Analisis Rasio atas Kemampulabaan PT Holcim Indonesia Tbk}

\section{Gross Profit Margin}

Berikut ini adalah grafik perbandingan rasio Gross Profit Margin SMCB dan Rata-Rata Industri.

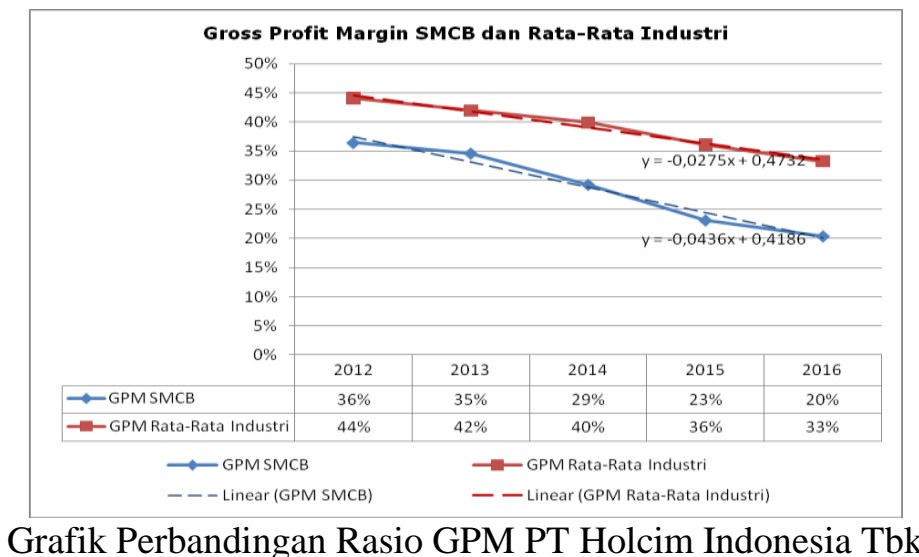

Grafik Perbandingan Rasio GPM PT Holcim Indonesia Tbk 
Grafik menunjukkan bahwa tren rasio GPM baik SMCB maupun rata-rata industri menurun rasio ini merupakan dampak dari rasio HPP per penjualan yang meningkat. Penurunan tren yang terjadi pada SMCB lebih besar daripada penurunan pada rata-rata industri dan hasil angka GPM SMCB pun berada dibawah angka rata-rata. Angka rasio GPM SMCB yang berada dibawah rata-rata menunjukkan bahwa dalam hal menghasilkan laba kotor terhadap penjualan, SMCB masih belum optimal dan menyaingi industri dan tren penurunan rasio GPM SMCB yang terjadi akibat laba kotor yang menurun seperti yang telah dijelaskan sebelumnya sedangkan penjualan SMCB cenderung stabil.

\section{Operating Profit Margin}

Berikut ini adalah grafik perbandingan rasio Operating Profit Margin SMCB dan Rata-Rata Industri.

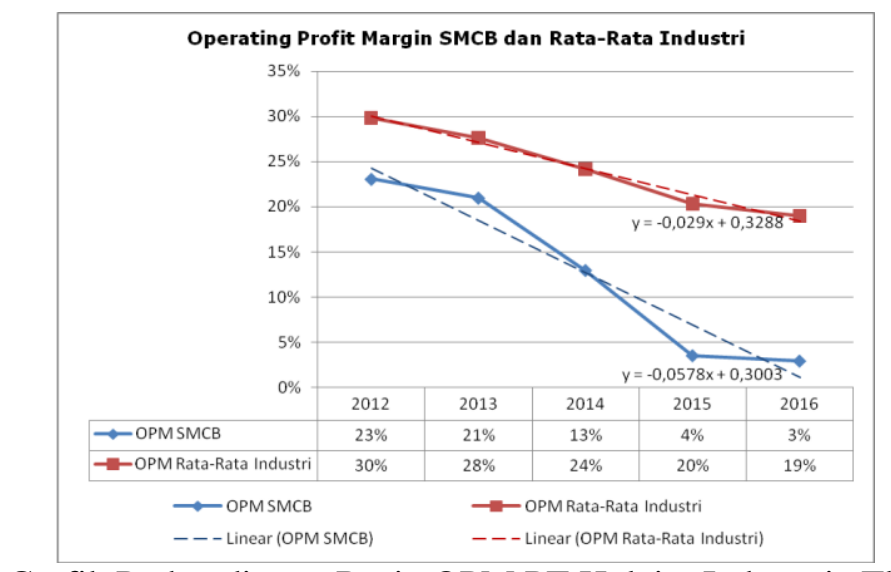

Grafik Perbandingan Rasio OPM PT Holcim Indonesia Tbk dan Rata-Rata Industri tahun 2012-2016

Grafik menunjukkan bahwa garis rasio OPM yang dihasilkan SMCB dan rata-rata industri sama-sama memiliki tren yang menurun, namun penurunan rasio OPM SMCB lebih besar daripada rata-rata industri. Rasio OPM SMCB tersebut menurun akibat laba usaha SMCB yang menurun, terutama pada tahun 2014 dan 2015. Namun pada tahun 2016, sesuai dengan laba usaha SMCB yang tidak kembali menurun tajam, maka rasio OPM SMCB pada tahun 2015-2016 mendatar.

Berdasarkan rasio OPM tersebut juga dapat dilihat bahwa dari penjualan yang dihasilkan, setelah dikurangi oleh biaya pokok dan biaya operasional yang 
dikeluarkan, laba usaha yang didapatkan oleh SMCB selama tiga tahun tersebut tidak lebih dari $25 \%$ dan semakin berjalannya waktu, prosentase laba usaha terhadap penjualan SMCB semakin kecil, bahkan tidak mencapai 5\% dan belum lagi dikurangi oleh biaya lainnya dan pajak.

\section{Net Profit Margin}

Berikut ini adalah grafik perbandingan rasio Net Profit Margin SMCB dan Rata-Rata Industri.

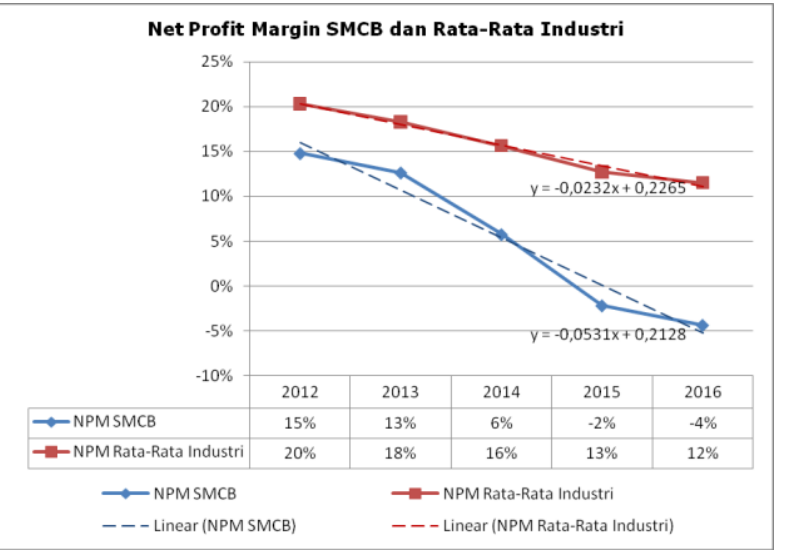

Grafik Perbandingan Rasio NPM PT Holcim Indonesia Tbk dan Rata-Rata Industri tahun 2012-2016

Grafik menunjukkan bahwa NPM SMCB dan NPM rata-rata industri menurun. Namun penurunan NPM SMCB lebih besar daripada penurunan pada rata-rata industri dan garis rasio NPM SMCB juga berada dibawah garis NPM rata-rata industri. Hal ini karena pergerakan dari laba bersih yang dihasilkan oleh SMCB terhadap penjualan yaitu semakin menurun. Kemudian dari dari total penjualan 100\% SMCB hanya mampu menghasilkan laba bersih yang dapat diatribusikan kepada pemegang saham maksimal 15\% selama lima tahun tersebut bahkan pada 2015 dan 2016 SMCB mendapatkan kerugian.

\section{Return on Asset}

Berikut ini adalah grafik perbandingan rasio Return On Asset SMCB dan Rata-Rata Industri. 


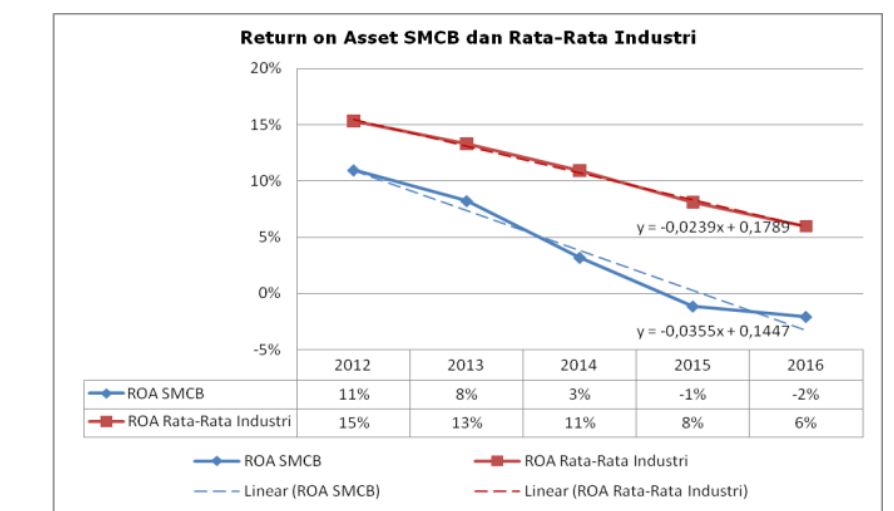

Grafik Perbandingan Rasio ROA PT Holcim Indonesia Tbk dan Rata-Rata Industri tahun 2012-2016

Grafik menunjukkan bahwa kemampuan SMCB dan rata-rata industri dalam menghasilkan EBIT terhadap aset yang dimilikinya menurun yang disebabkan oleh peningkatan aset yang terjadi baik pada SMCB maupun rata-rata industri, sedangkan EBIT SMCB maupun rata-rata industri menurun. Dalam grafik tersebut diatas juga memperlihatkan penurunan rasio ROA yang dimiliki oleh SMCB lebih besar daripada penurunan rasio ROA rata-rata industri dan garis rasio ROA SMCB pun berada dibawah garis rata-rata industri. Hal ini memberikan arti bahwa dalam menghasilkan keuntungan jika dibandingkan dengan aset yang dimiliki, SMCB masih belum optimal karena berada dibawah rata-rata.

\section{Return on Equity}

Berikut ini adalah grafik perbandingan rasio Return On Equity SMCB dan Rata-Rata Industri.

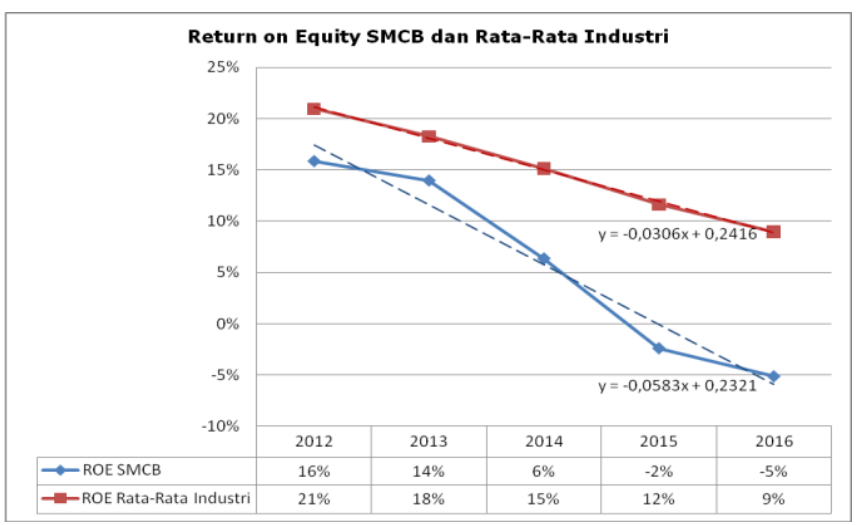

Grafik Perbandingan Rasio ROE PT Holcim Indonesia Tbk dan Rata-Rata Industri tahun 2012-2016 
Grafik menunjukkan bahwa kemampuan SMCB dan rata-rata industri menghasilkan laba yang terhadap ekuitas yang dimiliki, menurun. Hal ini tidak lepas dari penurunan laba bersih yang terjadi lebih tinggi daripada penurunan ekuitas yang dimiliki.

\section{Analisis Kinerja Saham PT Holcim Indonesia Tbk}

\section{Harga Saham}

Berikut ini adalah penyajian kembali grafik pergerakan harga pasar saham PT Holcim Indonesia Tbk tahun 2012-2016.

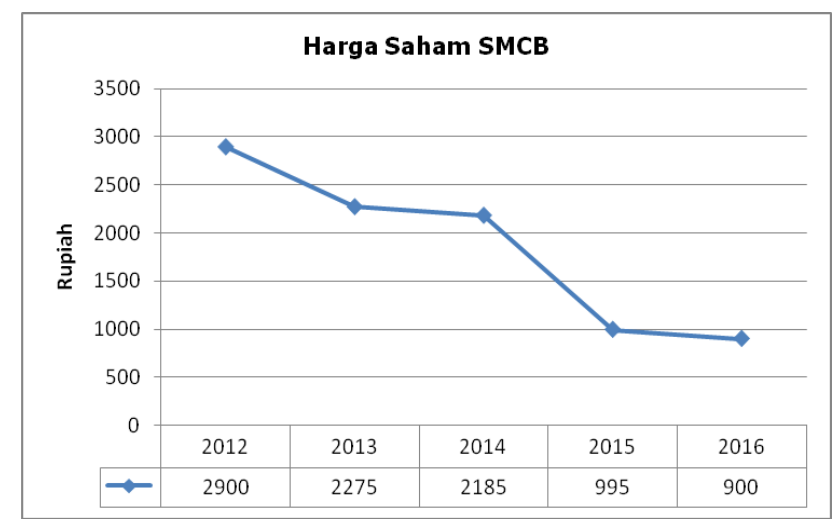

Grafik Pergerakan Harga Saham PT Holcim Indonesia Tbk tahun 2012-2016

Grafik menunjukkan harga pasar saham SMCB terus menurun dari tahun 2012-2016. Hal tersebut disebabkan oleh kondisi sektor/ industri semen yang sedang menurun dimana akibat oversupply yang terjadi maka penjualan perusahaan-perusahaan dalam sektor semen di Indonesia juga menurun. Oleh karena itu menurunnya tren harga saham pun tidak hanya terjadi pada SMCB saja tetapi pada seluruh saham yang berada di sektor industri semen akibat kondisi yang serupa. Namun khususnya pada tahun 2013, seperti yang telah disebutkan pada analisis makroekonomi yaitu kurs nilai tukar, IHSG secara keseluruhan memang menurun yang diakibatkan oleh keluarnya arus modal asing dari Indonesia.

Kemudian pada tahun 2015, seluruh saham pada sektor industri semen menurun secara signifikan akibat kebijakan penurunan harga semen yang ditetapkan oleh pemerintah. SMCB sebenarnya dapat bertahan terhadap kondisi tersebut dalam hal penjualan, karena penjualan SMCB masih meningkat, namun karena pengelolaan keuangan internal dalam hal tidak efisiennya penggunaan biaya, mengakibatkan laba SMCB menurun sehingga menurun pula kepercayaan 
investor terhadap saham SMCB dan terlihat pada gambar 4.43 harga saham SMCB menurun paling signifikan pada tahun tersebut.

\section{Nilai Buku}

Berikut ini adalah grafik nilai buku / book value PT Holcim Indonesia Tbk tahun 2012-2016.

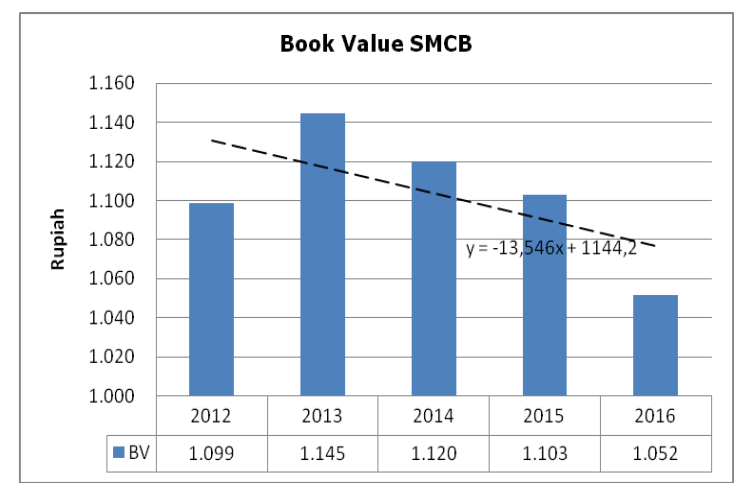

Grafik Pergerakan Nilai Buku/Book Value PT Holcim Indonesia Tbk tahun 2012-2016

Grafik menunjukkan nilai buku SMCB yang terus menurun walaupun nilai buku SMCB masih berada diatas angka Rp1000, namun hal ini menunjukkan bahwa jika SMCB dilikuidasi, maka jumlah tersebutlah yang dapat diterima oleh para pemegang saham SMCB per lembar sahamnya.

\section{Analisis Rasio atas Kinerja Saham PT Holcim Indonesia Tbk}

\section{Price per Earning Ratio}

Berikut ini adalah grafik perbandingan Price per Earning Ratio SMCB dan Rata-Rata Industri.

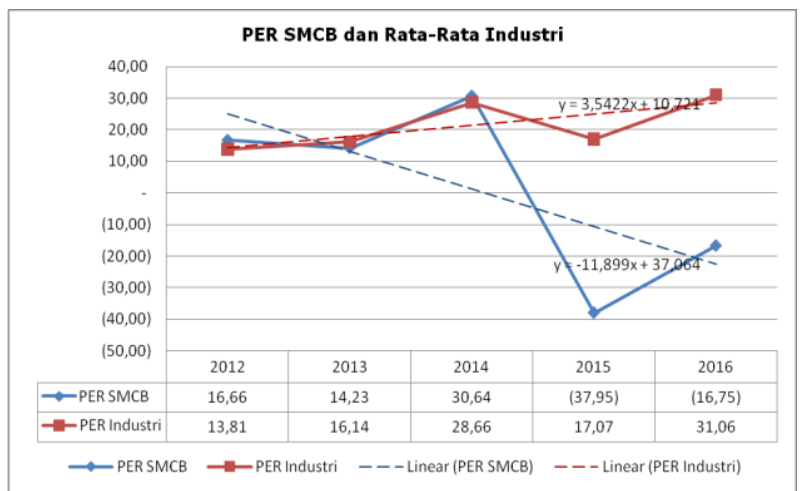

Grafik Perbandingan Rasio PER PT Holcim Indonesia Tbk dan Rata-Rata Industri tahun 2012-2016

Grafik menunjukkan rasio PER yang dimilki oleh SMCB dan rasio PER rata-rata indsutri memiliki tren yang berkebalikan. Pada tahun 2012, PER SMCB 
berada diatas PER rata-rata industri yang memberikan arti bahwa pada tahun tersebut harga SMCB dapat dikatakan relatif mahal karena overvalued dimana dengan harga pasar yang ada yaitu 2900, investor harus membayar untuk mendapatkan EPS sejumlah Rp174. Sehingga pada tahun 2012 tersebut investor yang telah memiliki potensi keuntungan dalam hal capital gain di sarankan untuk menjual sahamnya untuk kembali membeli pada harga yang rendah.

Namun mulai tahun 2013, PER SMCB mulai berada dibawah PER rata-rata industri atau undervalued dimana saham SMCB dapat dikatakan relatif murah sehingga disarankan kepada investor untuk melakukan pembelian dan bagi investor yang telah memiliki saham SMCB untuk terus menahan sahamnya jika terus ada indikasi peningkatan harga. Tetapi mulai tahun 2015 PER SMCB menjadi negatif, pada kondisi ini, saham SMCB tidak dapat dikatakan juga murah atau mahal akibat EPS yang negatif atau kerugian yang dialami oleh SMCB.

\section{Price per Book Value}

Berikut ini adalah grafik perbandingan Rasio Price per Book Value SMCB dan Rata-Rata Industri.

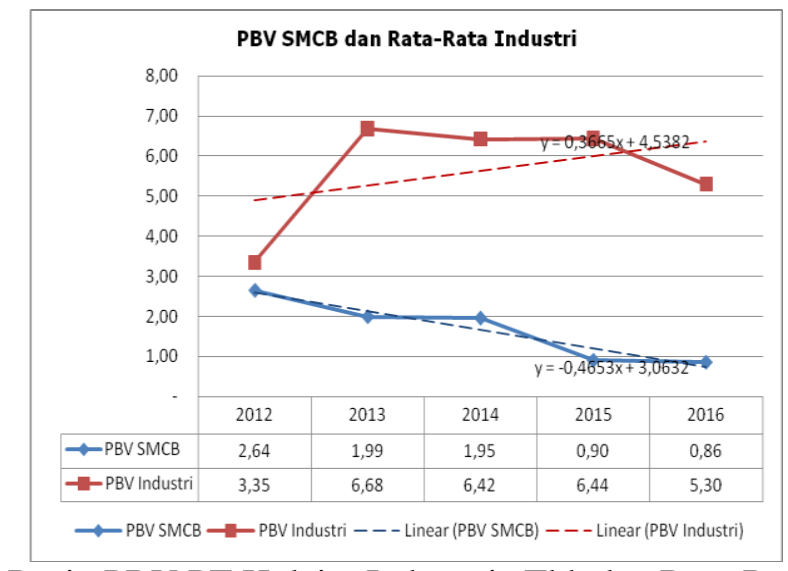

Grafik Perbandingan Rasio PBV PT Holcim Indonesia Tbk dan Rata-Rata Industri tahun 2012-2016

Grafik menunjukkan tren PBV SMCB dan rata-rata industri yang juga berlawanan arah. Jika dilihat berdasarkan rasio PBV, saham SMCB selama lima tahun berada pada posisi undervalued karena berada dibawah garis PBV rata-rata industri. Sehingga investor disarankan untuk melakukan pembelian terhadap saham SMCB atau bagi investor yang memiliki saham SMCB dapat menahan 
sahamnya karena jika dilihat dari rasio PBV, SMCB masih mampu memberikan imbal hasil dari book value yang dimiliki oleh SMC

\section{SIMPULAN}

Berikut ini adalah ringkasan analisis kinerja keuangan dan kinerja saham PT Holcim Indonesia Tbk dan Rata-Rata Industri.

Ringkasan Kinerja PT Holcim Indonesia Tbk tahun 2012-2016

\begin{tabular}{|c|c|c|}
\hline \multirow[b]{2}{*}{ Keterangan } & \multicolumn{2}{|c|}{ Rata-rata (Periode 2012-2016) } \\
\hline & $\begin{array}{l}\text { PT Holcim Indonesia } \\
\text { Tbk }\end{array}$ & $\begin{array}{c}\text { Rata-Rata } \\
\text { Industri }\end{array}$ \\
\hline \multicolumn{3}{|l|}{ KINERJA KEUANGAN } \\
\hline \multicolumn{3}{|l|}{ Kemampulabaan } \\
\hline \multicolumn{3}{|l|}{ Profitabilitas : } \\
\hline HPP/Penjualan (\%) & 71 & 61 \\
\hline BO/Penjualan (\%) & 16 & 15 \\
\hline Operating Profit Margin (\%) & 13 & 24 \\
\hline Return on Asset (\%) & 4 & 11 \\
\hline \multicolumn{3}{|l|}{ Manajemen Aset } \\
\hline \multicolumn{3}{|l|}{ Aktivitas dan Profitabilitas: } \\
\hline Fixed Asset Turn Over (X) & 0,69 & 1,09 \\
\hline EBIT/Fixed Asset $(\%)$ & 10 & 27 \\
\hline Inventory Turn Over $(\mathrm{X})$ & 11,21 & 6,45 \\
\hline Account Recaivable Turn Over (X) & 9,56 & 7,55 \\
\hline \multicolumn{3}{|l|}{ Likuiditas: } \\
\hline Current Ratio (X) & 0,75 & 2,18 \\
\hline \multicolumn{3}{|l|}{ Pendanaan } \\
\hline \multicolumn{3}{|l|}{ Rasio Solvabilitas : } \\
\hline Debt to Asset Ratio (\%) & 47 & 29 \\
\hline Debt to Equity Ratio (\%) & 93 & 41 \\
\hline \multicolumn{3}{|l|}{ Coverage: } \\
\hline TIE (X) & 6,51 & 24,64 \\
\hline \multicolumn{3}{|l|}{ Aktivitas : } \\
\hline Accout Payable Turn Over (X) & 0,96 & 1,40 \\
\hline \multicolumn{3}{|l|}{ KINERJA SAHAM } \\
\hline \multicolumn{3}{|l|}{ Rasio Pasar : } \\
\hline $\operatorname{PER}(\mathrm{X})$ & 1,37 & 21,35 \\
\hline $\mathrm{PBV}(\mathrm{X})$ & 1,67 & 5,64 \\
\hline
\end{tabular}


Berdasarkan penelitian dan analisis yang dilakukan, dapat disimpulkan beberapa hal mengenai kinerja keuangan dan kinerja saham PT Holcim Indonesia Tbk mulai tahun 2012-2016.

1. Dalam membiayai usahanya, PT Holcim Indonesia Tbk lebih dominan menggunakan utang dan terus meningkat. Namun kemampuan melakukan pembayaran bunga semakin menurun yang disebabkan oleh laba PT Holcim Indonesia yang juga menurun selama lima tahun tersebut. Kemudian berdasarkan perputaran utang, perputaran utang yang dimiliki oleh PT Holcim Indonesia lebih kecil dari pada rata-rata Industri dan perputaran utang serta rata-rata umur utangnya lebih lambat daripada perputaran piutang dan rata-rata umur piutang.

2. Manajemen aset PT Holcim Indonesia Tbk menunjukkan bahwa selama lima tahun tersebut PT Holcim Indonesia Tbk fokus pada ekspansi atau perluasan bisnisnya, dibuktikan dengan adanya tiga pembangunan dan satu kegiatan akuisisi. Namun hal tersebut tidak langsung memberikan dampak yang baik pada penjualan dan laba walaupun pembangunan tersebut selesai dilakukan, dimana ekspansi merupakan investasi yang bersifat jangka jangka panjang sehingga imbal hasil yang terlihat pun tidak akan secara langsung didapatkan. Khususnya karena kegiatan-kegiatan tersebut dilakukan pada saat kondisi industri sedang berada pada kondisi oversupply, sehingga permintaan akan semen juga menurun walaupun produksi yang dilakukan dapat lebih tinggi.

Terdapat hal yang baik dalam manajemen aset PT Holcim Indonesia Tbk, yaitu perputaran persediaan dan perputaran piutang yang dimiliki PT Holcim Indonesia Tbk lebih baik daripada rata-rata industri.

3. Dalam hal kemampulabaan, PT Holcim Indonesia Tbk mampu menghasilkan penjualan yang cenderung stabil selama lima tahun tersebut dibandingkan dengan rata-rata industri yang menurun. Namun inefisiensi biaya yang terjadi baik pada biaya pokok penjualan dan biaya operasional membuat PT Holcim Indonesia Tbk mengalami penurunan laba hingga mengalami kerugian pada tahun 2015 dan tahun 2016. 
4. Harga pasar saham PT Holcim Indonesia Tbk selama lima tahun terus menurun berkaitan dengan kondisi eksternal yang terjadi sehingga seluruh harga pasar saham perusahaan semen menurun. Namun harga pasar saham PT Holcim Indonesia Tbk lebih menurun lagi akibat kinerja perusahaan juga menurun. Kemudian berdasarkan analisis nilai wajar, saham PT Holcim Indonesia Tbk saat ini berada pada posisi undervalue, yaitu relatif murah sehingga investor disarankan untuk membeli dan/atau menahan saham PT Holcim Indonesia Tbk.

\section{REFERENSI}

Agus, R. Sartono. 2010. Manajemen Keuangan Teori dan Aplikasi, Edisi Keempat. Yogyakarta : BPFE.

Atmaja, Lukas Setia. 2008. Teori dan Praktek Manajemen Keuangan. Yogyakarta: CV Andi Offset

Brealey, Myers, \& Marcus. 2002. Dasar-dasar Manajemen Keuangan Perusahaan. Edisi Kelima Jilid 1. Jakarta :Erlangga

Brealey, Richard A, Stewart C. Myers and Alan J. Marcus. 2007. Dasar-dasar Manajemen Keuangan Perusahaan, jilid 1. Jakarta : Erlangga

Bodie, Zvie, Alex Kane, and Alan J. Marcus. 2014. Alih bahasa oleh Romi Bhakti Hartarto dan Zuliani Dalimunthe. Manajemen Portofolio dan Investasi. Jakarta: Salemba Empat

Budiman, Raymond. 2017. Intermediate Accounting. Yogyakarta: BPFE

Brigham, Eugene F and Joel F Houston. 2011. Alih bahasa oleh Ali Akbar Yulianto. Dasar-dasar Manajemen Keuangan Edisi 11 Buku 2. Jakarta:

Fahmi, Irham. 2013. Rahasia Saham dan Obligasi. Bandung: Alfabeta

Fahmi, Irham. 2014. Studi Kelayakan Bisnis dan Keputusan Investasi. Jakarta: Mitra Wacana Media

Halim, Abdul. 2005. Analisis Investasi. Jakarta: Salemba Empat

Halim, Abdul. 2015. Manajemen Keuangan Bisnis Konsep dan Aplikasinya. Jakarta: Mitra Wacana Media

Herry. 2015. Analisis Kinerja Manajemen. Jakarta : PT Grasindo. 
Horne, James C. Van and John M. Wachowicz, Jr. 2005. Alih bahasa oleh Dewi Fitriasari dn Deny Arnos Kwary. Prinsip-prinsip Manajemen Keuangan Edisi 12 Buku 1. Jakarta: Salemba Empat

Horne, James C. Van and John M. Wachowicz, Jr. 2007. Alih bahasa oleh Dewi Fitriasari dn Deny Arnos Kwary. Prinsip-prinsip Manajemen Keuangan Edisi 12 Buku 2. Jakarta: Salemba Empat

Horne, James C Van \& John M. Wachowicz, JR. 2005. Prinsip-prinsip Manajemen Keuangan. Penerjemah: Dewi Fitriasari dan Deny Arnos Kwary. Jakarta: Salemba Empat.

Husnan, Suad dan Enny Pudjiastuti. 2006. Dasar-Dasar Manajemen Keuangan. UPP STIM YKPN : Yogyakarta.

Kasmir. 2011. Analisis Laporan Keuangan. Jakarta : PT Raja Grafindo Persada.

Keown, Arthur J., John D. Martin, J. William Petty, dan David F. Scott, JR. 2004. Manajemen Kuangan: Prinsip-prinsip dan Aplikasi. Edisi 9. Jilid 1. Jakarta: PT Intermasa Haryandini

Khim, Soei. 2013. Analisis Pendanaan Bauran, Economic Value Added (EVA), Terhadap Market Value Added (MVA). Skripsi. Sekolah Tinggi Ilmu Ekonomi Kesatuan, Bogor

Liliani. 2015. Analisis Weighted Average Cost of Capital dan Leverage Terhadap Nilai Perusahaan. Skripsi. Sekolah Tinggi Ilmu Ekonomi Kesatuan, Bogor Martalena dan Maya Malinda. 2011. Pengantar Pasar Modal. Yogyakarta: ANDI Murhadi, Werner R. 2009. Analisis Saham Pendekatan Fundamental. Jakarta Barat: PT Indeks

Murhadi, Werner R. 2013. Analisis Laporan Keuangan Proyeksi dan Valuasi Saham. Jakarta: Salemba Empat

Pertiwi, Dina Indah. 2014. Analisis Kinerja Saham Dilihat Dari Risk Dan Expected Return Akibat Right Issue Terhadap Frekuensi Saham. Skripsi. Sekolah Tinggi Ilmu Ekonomi Kesatuan, Bogor

Pearce, John A dan Richard B. Robinson, Jr. 2014. Alih bahasa oleh Nia Pramita Sari. Manajemen Strategi. Edisi 12 Buku 1. Jakarta : Salemba Empat. 
Ross, Westerfield dan Jordan. 2009. Alih bahasa oleh Ali akbar yulianto, Rafika Yuniasih dan Christine. Pengantar Keuangan Perusahaan. Edisi 8. Buku 2. Jakarta: Salemba Empat

Samsul, Mohamad. 2015. Pasar Modal dan Manajemen Portofolio. Edisi 2. Jakarta: Erlangga

Sjahrial, Dermawan. 2012. Pengantar Manajemen Keuangan. Edisi 4. Jakarta : Mitra Wacana Media.

Subramanyam, K.R. dan John J. Wild. 2010. Alih bahasa oleh Dewi Yanti Analisis Laporan Keuangan. Edisi 10. Buku 1. Jakarta: Salemba Empat

Sutrisno. 2009. Manajemen Keuangan Teori, Konsep dan Aplikasi. Yogyakarta: Ekonisia.

Tampubolon, Manahan. 2008. Manajemen Keuangan. Edisi pertama. Jakarta : Mitra Wacana Media

Tandelilin, Eduardus. 2001. Analisis Investasi dan Manajemen Portofolio. Yogyakarta : BPFE-Yogyakarta

The Indonesia Capital Market Institute. 2010. Modul Wakil Perantara Pedagang Efek

Bursa Efek Indonesia. 2010. Saham. Diambil dari: http://www.idx.co.id/idid/beranda/produkdanlayanan/saham.aspx (diakses September 2017)

Heze, El. 2016. Analisis Fundamental Saham - Return on Asset (ROA). Diambil dari: http://www.sahamgain.com/2016/09/analisis- fundamental-sahamreturn-on.html (diakses September 2017)

Achmad, N. and Srihandoko, W., PENGARUH STOCK BUYBACK TERHADAP KINERJA SAHAM DAN KINERJA KEUANGAN.

Achmad, N., 2008. Teori Manajemen Keuangan. Bogor: Kesatuan Press.(Diktat Kuliah).

RACHMAN, M.R., ACHMAD, N. and WIBOWO, W., ANALISA PERBANDINGAN RESIKO INVESTASI DI BERSA EFEK INDONESIA DAN BURSA BERJANGKA JAKARTA DARI PERSPEKTIF ANALISA TEKNIKAL. 
Iriyadi, I., Pamungkas, B. and Gunawan, L.G., 2015. Sistem Informasi Akuntansi Dalam Kaitannya Dengan Laporan Biaya Produksi Pada Perusahaan CV Surya Pratama Gemilang. Jurnal Ilmiah Akuntansi Kesatuan, 3(3).

Mekaniwati, A., 2017. Analisis Kepuasan dan Loyalias Konsumen Roti Unyil Venus di Bogor. Jurnal Ilmiah Manajemen Kesatuan, 5(2), p.080-090

Adi, S., Martani, D., Pamungkas, B. and Simanjuntak, R.A., 2016. Analysis of the quality of performance report of the local government on websites: Indonesian case. Cogent Business \& Management, 3(1), p.1229393.

Listari, S. and Pardede, R.P., 2017. Pengaruh Fluktuasi Suku Bunga Kredit KURS terhadap Profitabilitas. Jurnal Ilmiah Akuntansi Kesatuan, 5(1), p.8-14.

Jasmadeti, J. and Wahyuningsih, D., 2017. Penyusunan Dan Analisa Laporan Keuangan Dalam Pengambilan Keputusan Pada Usaha Kecil Menengah (Studi Kasus Cv. Yogi Tas, Bogor-Jawa Barat). e-prosiding, 1(1).

Marlina, T., Danial, M. and Susmiatik, S., 2015. Peranan Sistem Penjualan Dalam Kaitannya Dengan Kolektibilitas Piutang (Studi Kasus pada PT. Liefarel Multiniaga Lestari). Jurnal Ilmiah Akuntansi Kesatuan, 3(3).

Yudha, A., Marlina, T. and Fahmi, A., 2017. Pelatihan Membuat Lapotan Keuangan Dengan Microsoft Excel BUMDes Pagelaran. Jurnal Abdimas, l(1), p.9-12. 